\title{
Developing Teaching Skills through the School Practicum in Turkey: A Metasynthesis Study
}

\author{
Mükerrem Akbulut Taş ${ }^{1}$, Ayşegül Karabay ${ }^{2}$ \\ ${ }^{1}$ Çukurova University, Education Faculty, Departments of Educational Sciences, 01330 Sarıçam Adana, Turkey \\ ${ }^{2}$ Çukurova University, Education Faculty, Department of Primary Education, 01330 Sarıçam Adana, Turkey \\ Correspondence: Mükerrem Akbulut Taş, Çukurova University, Education Faculty, Departments of Educational \\ Sciences, 01330 Sarıçam Adana, Turkey.
}

Received: August 17, 2016

doi:10.11114/jets.v4i11.1813

\author{
Accepted: September 13, $2016 \quad$ Online Published: September 27, 2016
}

URL: http://dx.doi.org/10.11114/jets.v4i11.1813

\begin{abstract}
Using a metasynthesis approach, this study examined general teaching skills in previous studies on school practicum. The results and suggestions from 53 qualitative primary research studies that focused on school practicum in Turkey were reviewed. Data were collected using document analysis and content analysis using the NVivo10 programme. The results revealed that existing studies on practicum processes have focused mainly on pre-service teacher problems, such as classroom management, teaching management and the transformation of theoretical knowledge to practice; however, there was significantly less discussion on the development of teaching skills. There was also a lack of focus on the development of pre-service teaching skills, mentor interactions, integration of content and pedagogical knowledge and content organization and presentation. It was concluded that these areas require more detailed research.
\end{abstract}

Keywords: practicum, pre-service teacher education, teaching skills, content organization skills

\section{Introduction}

In pre-service teacher education, teaching skills are acquired through linking theory and practice in real classroom environments. Richardson-Koehler (1988) emphasized the importance of pre-service teachers gaining teaching experience by associating theory and practice (as cited in Kauffman 1992). Therefore, the school practicum is an important part of pre-service teacher education as it provides the pre-service teacher with the opportunity to apply teaching and learning knowledge and skills in real classroom environments (Qazi et al. 2012). However, it has been found in research on the school practicum that there is a significant gap between theory and practice in pre-service teacher education (Allen \& Wright 2014; Korthagen \& Kessels 1999; Tok 2010; van Velzen et al. 2012). Scheeler (2008) argued that pre-service teacher education institutions generally prepared teacher education students for ideal teaching conditions; thus, even though pre-service teachers learn effective teaching skills, they are often unable to use these in real classroom settings. Pre-service teaching research has shown concern for the apparent lack of connection between theory and practice and has raised questions as to the best way to integrate theory and practice and the ideal organization of realistic teaching environments (Oonk 2009).

Research has found that the school practicum is valuable for development of teaching skills for the teacher education students. Graham (2005) found that pre-service teachers' beliefs, views, knowledge and skills regarding assessment and planning were best developed in real classroom settings with the guidance of a mentor. In a study by Choy et al. (2013), it was found that beginning teachers' planning and classroom management skills and teaching strategies increased significantly in the first year of pre-service education. Similarly, in studies in Turkey, it was found that the school practicum increased in-class teaching skills, self-efficacy, and developed positive attitudes to teaching and the teaching profession (Koc 2012; Ozder et al. 2014). Many studies have investigated the development of teaching skills using micro teaching techniques, which were found to be effective (Bakir 2014; Kucukoglu et al. 2012; Saban \& Coklar 2013; Sen 2010).

With this background, to fully understand the general pattern as to how teaching skills can develop through the school practicum, an analysis of previous studies completed on school practicum is important. However, similar literature investigations with related expectations have been conducted. A systematic research review of school practicum was conducted by Lawson et al. (2015), in which problems and research gaps were identified. Kasapoglu (2015) 
systematically reviewed Turkish school experience and teaching practice studies from 2000 to 2010, but this analysis did not include studies on teaching skills. A systematic research review regarding the transfer of teaching skills to the real classroom environment was done by Scheeler (2008), from which four factors likely to support the sustainability of teaching skills were identified: using immediate feedback to promote efficient and effective acquisition of new skills, educating for mastery of specific teaching skills, programming for generalization and providing performance feedback in the classroom environment. Scheeler found that, even if pre-service teachers learn effective teaching skills, they often have problems generalizing or transferring the skills to a real classroom environment. There has not yet, however, been a systematic study conducted in Turkey that summarizes and examines current empirical studies as to the contribution of the school practicum on the development of teaching skills. A study of this nature can highlight possible research gaps, as well as consolidate the findings on possible teaching skill gaps or problems with the school practicum. The aim of this study, therefore, is to use a metasynthesis approach to examine the development of general teaching skills in school practicum studies.

In this study, the teaching skills considered to be in the scope of the teacher competencies recognized by the faculty-school partnership model were: content knowledge, pedagogical content knowledge, learning-teaching process (planning and teaching process), classroom management, communication, assessment and recording and other professional competencies (Koc et al. 1998). Consistent with the aim of this study, the following research questions were posed:

1. What is theoretical basis used in the Turkish studies?

2. What are the teaching skills identified and what teaching developments were noted?

3. What suggestions are given for the development of teaching skills?

\section{Method}

\subsection{Research Design}

This was a metasynthesis research. Metasynthesis is an approach in which findings from existing qualitative studies are integrated using qualitative methods (Savin-Baden \& Major 2010). The aim of metasynthesis is to make sense of concepts, categories or themes that have recurred in a series of studies so as to develop a comprehensive picture of the findings (Savin-Baden \& Major 2010). Data were collected using document analysis techniques.

\subsection{Data Sources}

Qualitative studies that focused directly on the school practicum in Turkey were selected. The data were gathered through database searches conducted on Cukurova University library, the Academic Social Sciences Index (ASOS), the Arastirmax-Science Publication Index, ULAKBIM and Google Scholar. The reference list in each relevant research article was examined for additional sources. The following key words were used in the search query: teaching practicum, school experience, teaching skills and teacher competencies. During the analysis process, articles were selected based on the following criteria:

1. Focus on school practicum in pre-service teacher education in Turkey

2. Empirical studies conducted using qualitative methods and data collection tools

3. Publication in a refereed journal (national and international)

4. Results, discussion, and suggestions regarding teaching skills

Selected articles were examined independently by two researchers to determine adherence to the selection criteria and then checked using the 'paper assessment form' prepared by each researcher. At the end of this assessment scoring, reliability was calculated to be $100 \%$. Finally, 101 quantitative and qualitative papers were selected, of which 53 qualitative studies complied with the selection criteria. Publication dates were restricted to between January 2003 and December 2014. The distribution of the analyzed studies in terms of aim, participants, type of qualitative research and data collection tools is shown in Tables 1, 2, and 3.

As seen in Table 1, 34 of the studies (64.15\%) were conducted to obtain perceptions and opinions regarding school practicum experiences (the benefit of the practicum, encountered problems, and suggestions) and 13 of the studies (24.53\%) were conducted to identify perceptions and opinions regarding teacher competencies in the school practicum. Three $(5.66 \%)$ other studies were conducted to obtain opinions regarding cooperation between stakeholders two $(3.77 \%)$ in the effect of the school practicum on forming bonds between theory and practice and one $(1.89 \%)$ in and the perceptions of pre-service teachers related to teacher and student roles in the school practicum. 
Table 1. Frequencies and percentage of primary research studies according to the aims

\begin{tabular}{|c|c|c|}
\hline Aim of Studies & f & $\%$ \\
\hline $\begin{array}{l}\text { Obtaining opinions and perceptions regarding school practicum experiences (The benefits of practice, encountered } \\
\text { problems and suggestions) }\end{array}$ & 34 & 64.15 \\
\hline Obtaining opinions and perceptions regarding teacher competencies in school practicum & 13 & 24.53 \\
\hline Obtaining opinions regarding cooperation between stakeholders in school practicum & 3 & 5.66 \\
\hline The effect of the school practicum on forming bonds between theory and practice & 2 & 3.77 \\
\hline The perceptions of pre-service teachers regarding teacher and student roles in the school practicum & 1 & 1.89 \\
\hline Total & 53 & 100 \\
\hline
\end{tabular}

Table 2. Frequencies and percentage of primary research studies based on participant type

\begin{tabular}{|c|c|c|c|}
\hline$\overline{\text { Participants }}$ & f & $\%$ & Studies \\
\hline $\begin{array}{l}\text { Pre-service teachers in various teacher } \\
\text { education programs (German, physical } \\
\text { education, science, elementary } \\
\text { mathematics, pre-school, special education } \\
\text { mental disability, elementary education, } \\
\text { social studies, Turkish language teaching) }\end{array}$ & 39 & 73.58 & $\begin{array}{l}\text { Akgun, Yildiz and Canbulat, 2003; Altintas and Gorgen, 2014; } \\
\text { Becit, Kurt and Kabakci, 2009; Cetintas and Genc, 2005; Cicek and } \\
\text { Ince, 2005; Ozden and Camli, 2011; Ekiz, 2006; Eraslan, 2008; } \\
\text { Eraslan, 2009; Ergenekon, Ozen and Batu, 2008; Guven, 2004; Kab } \\
\text { and Yilmaz, 2013; Kana, 2014; Koc and Yildiz, 2012; Ozen, } \\
\text { Ergenekon and Batu, 2009; Saracaloglu, Yilmaz, Cogmen and } \\
\text { Sahin, 2011; Simsek, 2013; Tasdere, 2014; Topkaya, Tokcan and } \\
\text { Kara, 2012; Yapici and Yapici, 2004; Yigit and Alev, 2007; } \\
\text { Yurdatapan, 2010; Basturk, 2009; Ozdemir and Canakci, 2005; } \\
\text { Paker, 2008; Sonmez and Can, 2010; Tok, 2010; Yigit and Alev, } \\
\text { 2005; Kavas and Bugay, 2009; Bekiroglu, Kahveci, Irez, Seker and } \\
\text { Cakir, 2010; Kilinc, 2014; Arikan, 2009; Tepeli and Caner, 2014; } \\
\text { Duman, 2013; Arslan, 2014; Yilmaz, 2006; Karaca and Aral, 2011; } \\
\text { Basturk, 2010; Yesilyurt and Semerci, 2012 }\end{array}$ \\
\hline Mentor teacher & 3 & 5.66 & $\begin{array}{l}\text { Akpinar, ColakandYigit, 2012; Yesilyurt and Semerci, 2011; Cakir, } \\
\text { Bekiroglu, Irez, Kahveci and Seker, } 2010\end{array}$ \\
\hline supervisor,mentor & 2 & 3.77 & Kocadere and Askar, 2013; Unver, 2003 \\
\hline
\end{tabular}

teacher and principals

Mentor teacher and principals $\quad 2 \quad 3.77 \quad$ Alkan, Simsek and Erdem, 2013; Simsek, Alkan and Erdem, 2013; Pre-service teachers, mentor-teacher and $1 \quad 1.89$ Nayir and Cinkir, 2014 principals

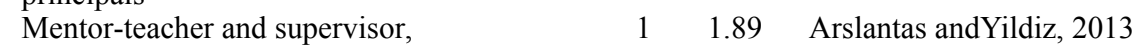

Pre-service teachers and mentor teacher $\quad 1 \quad 1.89 \quad$ Saritas, 2007

Pre-service teachers, mentor teacher and $1 \quad 1.89$ Unver and Kursunlu, 2014 supervisor,

$\begin{array}{llll}\text { Pre-service teachers and supervisor, } & 1 & 1.89 & \text { Dursun and Kuzu, } 2008\end{array}$

Practice coordinators, principals and mentor $1 \quad 1.89$ Goktas and Sad, 2014

teachers

Pre-service teachers, mentor teacher, $1 \quad 1.89$ Secer, Celikoz and Kayili, 2010 supervisor and coordinators Total $53 \quad 100$

As seen in Table 2, 39 of the reviewed papers (73.58\%) were conducted on pre-service teachers in a range of teacher education programs (German, physical education, science, elementary mathematics, pre-school, special education mental disability, elementary education, social studies, Turkish language teaching). Other studies were conducted with the focus on supervisors, mentor teachers, principals and coordinators and primary students.

From Table 3, 31 of the studies (58.49\%) did not mention a research type, $12(22.64 \%)$ were case studies, four $(7.55 \%)$ were descriptive, three $(5.66 \%)$ were phenomenologic, two $(3.77 \%)$ conducted qualitative research and one $(\% 1.89)$ was action research. In 33 of the studies $(62.26 \%)$, the sampling type was not indicated. In other studies, purposive sampling seven (13.20\%), convenience sampling four (7.55\%), typical case sampling three $(5.66 \%)$, simple random sampling three $(5.66 \%)$, maximum variety one $(1.89 \%)$, snowball-chain sampling one (1.89\%) and critical sampling one $(1.89 \%)$ were used. Sample sizes varied with 11 studies having between one and 15 participants, 15 between 16 and 30, seven between 31 and 45, four between 46 and 60, three between 61-75 and two between 76 and 90. Eleven studies had 115 participants and over. Data collection tools also varied across studies, with $29(54.72 \%)$ using an interview form, $11(20.76 \%)$ using open-ended question forms, five $(9.43 \%)$ based on documentation, five (9.43\%) using observation forms and three $(5.66 \%)$ using open- and closed-ended question forms. 
Table 3. Frequencies and percentage of primary research studies according to research type, sampling type, sampling size and data collection tools

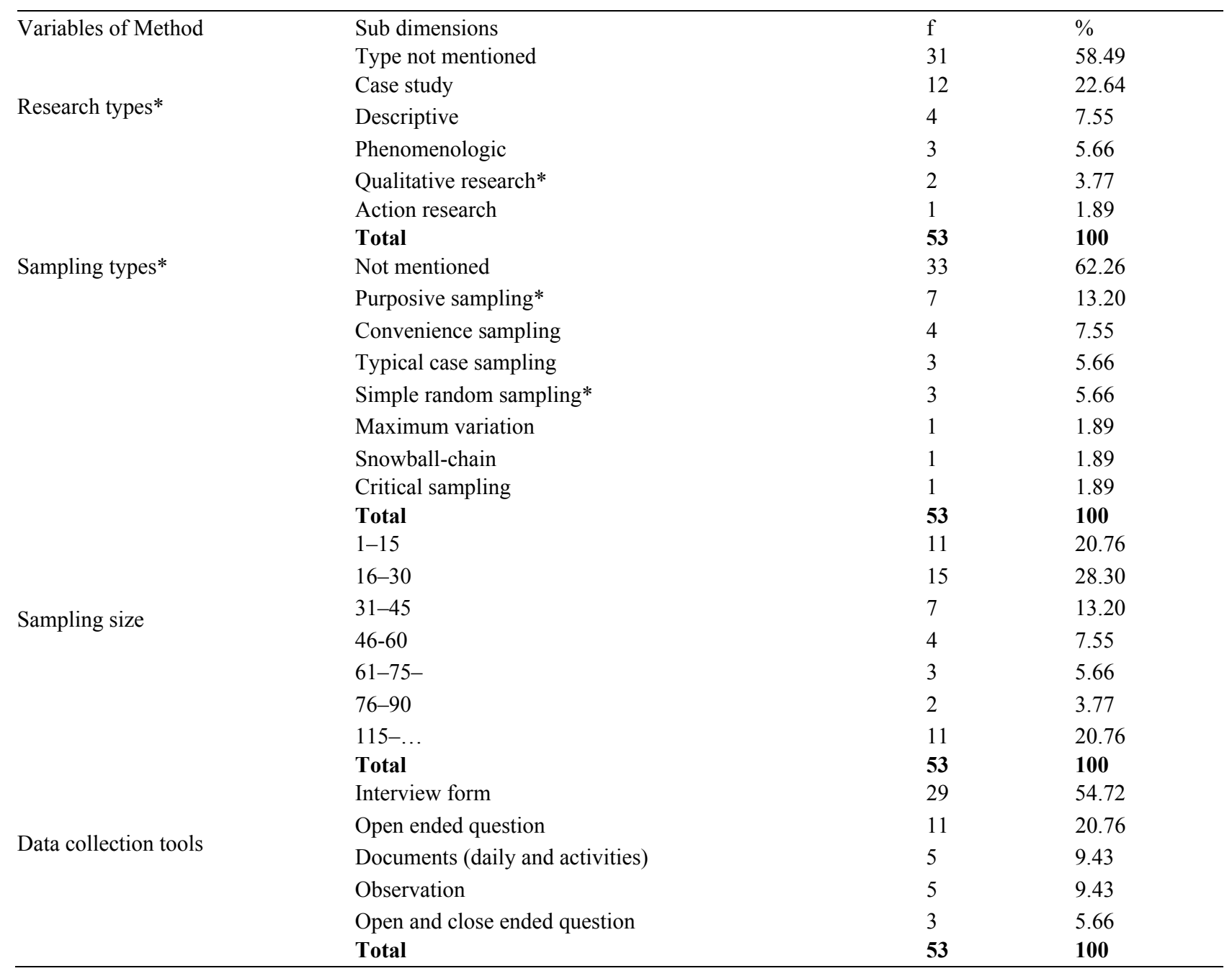

* In this study, during the classification of the sub dimensions of the variables for the research type and sampling type, in the 'method' part, the terminology mentioned by the respective authors was taken directly.

\subsection{Analysis Procedure}

Content analysis of the data was conducted using the NVvivo 10 package program. First, each of the reviewed studies was coded P1 (Practice 1) or P2 (Practice 2). Content analysis was done using open coding and axes coding, as in Strauss and Corbin (1990). The studies were analysed in terms of the theoretical basis, the results-discussions and the teaching skill suggestions/recommendations given. Subcategories were also identified. Main themes were then generated after all codes and sub categories had been established.

The data were coded separately by two researchers, from which 237 codes were identified. To examine consistency between the two coders' analyses, a meeting was held and differences in only five codes were found. These differences were resolved and the inter-coder reliability rate between the two codings was calculated using the reliability formula (Agreement / agreement + disagreement X 100) suggested by Miles and Huberman (1994). The inter-coder reliability score was $(237 / 237+5 \times 100)=97 \%$. It was also observed that the inter-rater reliability was high. In conceptualizing the codes and categories, the theoretical basis was also clarified. Finally, the frequency and percentage of the themes and codes were calculated. The findings were presented in model and tabular form.

\section{Findings}

In this section, we discuss the findings of the study in reference to the research questions.

\subsection{What was The Theoretical Basis in the Turkish Studies?}

The findings regarding the theories or models are presented in Figure 1. 


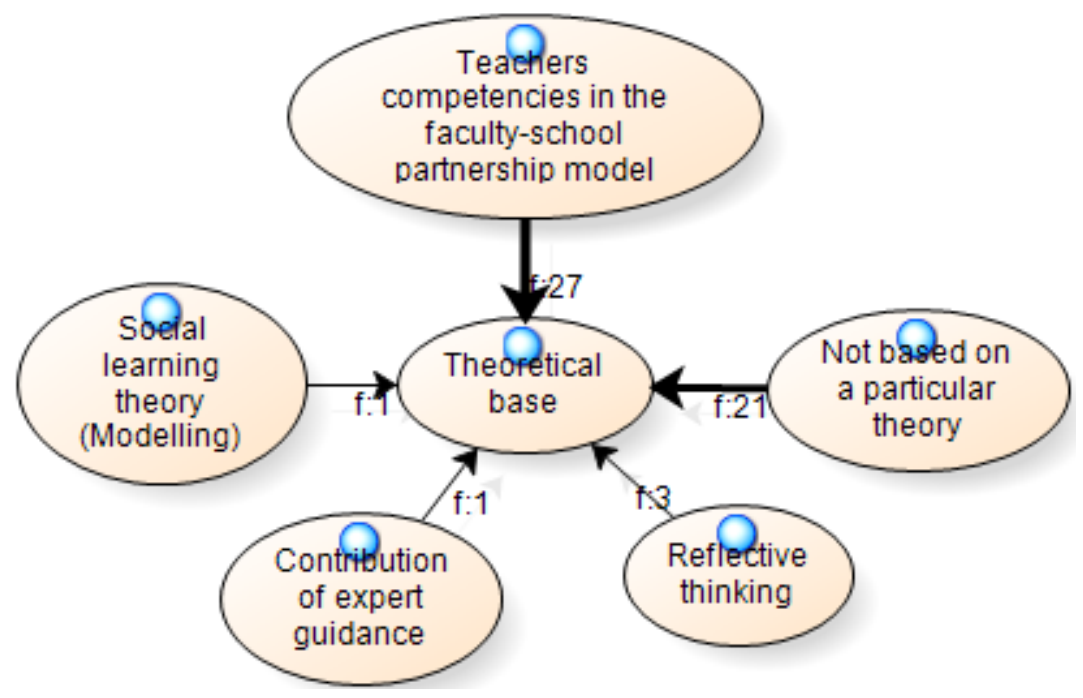

Figure 1. Themes regarding theoretical basis in the analyzed studies

As illustrated in Figure 1, 27 of the studies analyzed faculty-school partnerships, of which three focused on reflective thinking in teaching practice. Learning teacher roles (f:1) in relation to social learning theory and the contribution of expert guidance (f:1) was the basis in only one study. In 21 studies, no specific theoretical model was employed; however, the importance of teaching practice and the factors that affect the school experience were mentioned.

\subsection{What are the Teaching Skills Identified and What Teaching Developments Were Noted?}

The findings regarding the results in terms of teaching skills are given in Table 1 and Figure 2. Two main themes regarding teaching skills, positive aspects of practicum and encountered problems during practicum process, were identified. The positive aspects of the practicum are presented in Figure 2. As there were many codes for the problems encountered during practicum, these are presented in Table 4.

As shown in Figure 2, studies found that pre-service teachers acquired the following from the practicum; professional experience (f:15), communication skills (f:6); the opportunity to use different teaching methods and techniques (f:4) and classroom control (f:3). A few studies also identified positive attainments of others, preparing teaching materials (f:2), using suitable materials (f:2), acquiring efficacy in measurement and assessment activities (f:2), problem solving (f:1), associating content with introduction activities (f:1) and preparing effective lesson plans (f:2). 


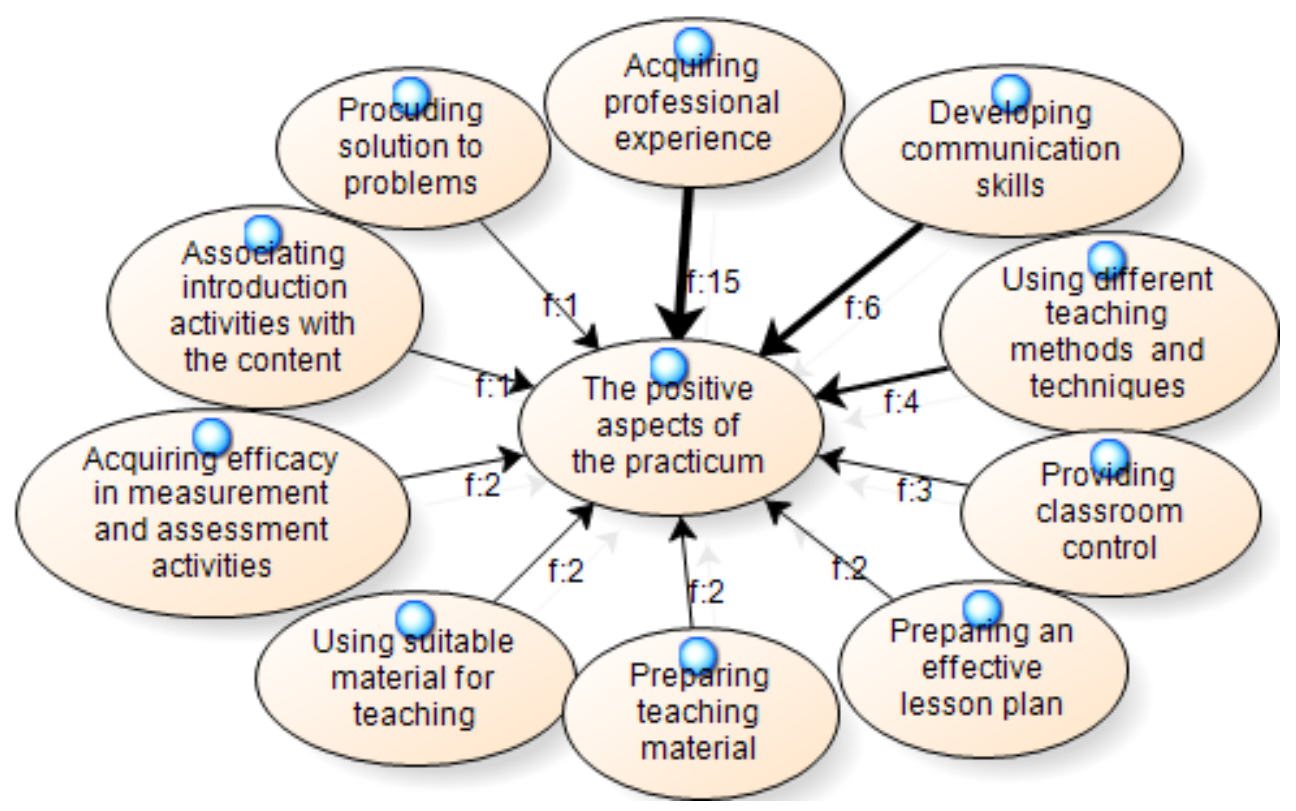

Figure 2. Themes related to the positive aspects of the practicum

As outlined in Table 4, the problems identified during the practicum were related to pedagogical content knowledge, planning skills and teaching skills in the classroom. Under the pedagogical content knowledge theme, pre-service teachers mostly had problems with missing and insufficient theoretical knowledge (f:7) and an insufficiency to transfer theoretical knowledge to practice (f:2). Under the planning skills theme, pre-service teachers mostly had problems with planning their teaching (f:6), and also had problems getting help during planning (f:3), getting help during the development of suitable material (f:2) and choosing strategies-methods and techniques (f:2).

Regarding teaching skills within class, pre-service teachers mostly had problems in teaching management (f:24) and classroom management (f:23) as well as problems in using teaching methods (f:6), benefiting from the teaching materials (f:4) and asking questions (f:3). 
Table 4. Frequencies and percentage of codes and themes regarding problems encountered during teaching practice

Problems Encountered During
Sub themes
Pedagogical content knowledg

Planning skills

Teaching

skills

within

classroom

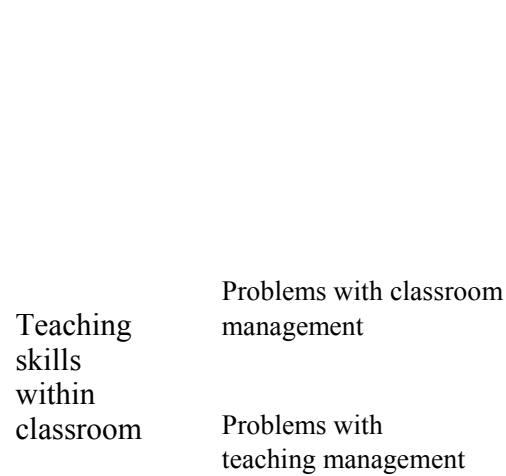

Problem in using teaching methods

Problems in providing teaching materials

Problems with asking question

\section{Codes}

Missing or insufficient theoretical knowledge $\mathrm{f}(\%)$ practice

Too much theoretical knowledge Insufficient practice lessons (in terms of time and quality)

Rarity of lessons on pedagogical content knowledge

Total

Having problems in planning teaching

Inability to get help during planning

Inability to get help during development of suitable material

Having problems in choosing
strategy-method-technique

Inability to associate teaching activities with the content

Inability to prepare lesson plan

Total

Insufficient

Inability to manage time

Inability to effectively communicate

Inability to achieve the level of the students

Having difficulty in making students effective

Inability to teach lessons effectively

Having problems with assessment

Inability to implement plan

Difficulty in giving instructions and explanations

Difficulty in concretizing the subject

Inability to summarize and repeat

Inability to be a cognitive coach

Inability to form heterogeneous groups

Inability to provide self-assessment

Using traditional methods

Difficulties in using special teaching methods

Difficulties in using different techniques

Just a few candidates using material

Insufficient use of materials

Limitation in activities due to materials shortage

Inability to ask effective questions

Inability to give effective answers

Inability to ask questions to the level of the students

Total
13

7

2

1

1

1

$12(13.64 \%)$

6

3

2

2

1

1

6

5

5

4

3

3

2

2

1

1

1

1

3

2

1

2

1

1

1

1

1

$61(69.32 \%)$

\subsection{What Suggestions are Given for the Development of Teaching Skills?}

In the reviewed studies, the findings regarding suggestions towards the development of teaching skills are presented in Figure 3. 


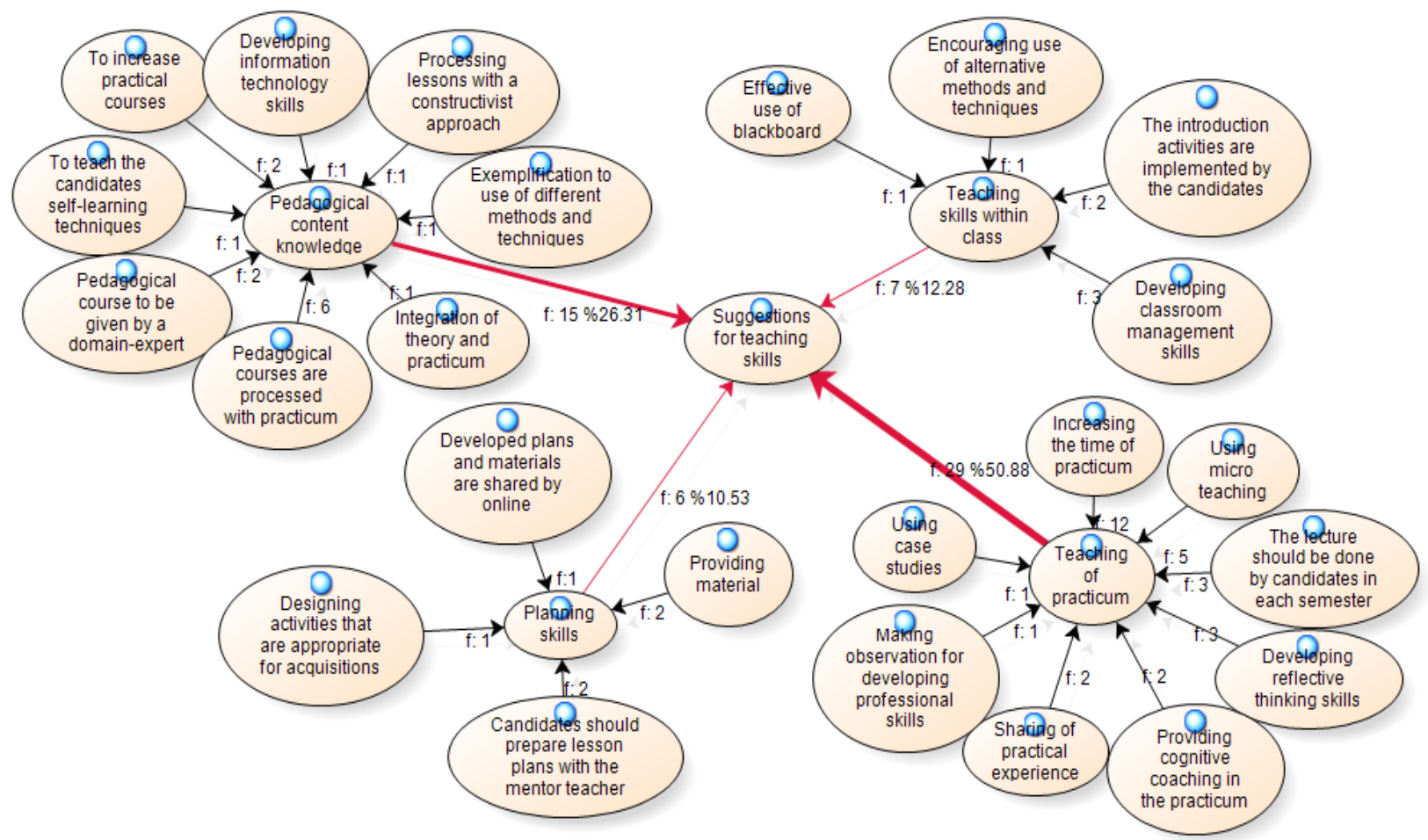

Figure 3. Themes regarding suggestions towards teaching skills in the practicum

As shown in Figure 3, the suggestions towards the development of teaching skills in the reviewed studies were collected under four themes: Teaching of practicum, teaching skills within class, planning skills, and pedagogical content knowledge. Most suggestions were related to practicum lesson instruction (f:29, 50.88\%) and pedagogical content knowledge (f:15, 26.31\%). For practicum instruction, most suggestions were related to increasing the practicum time (f:12). For pedagogical content knowledge, most suggestions related to practical teaching (f:6) and teaching lessons using micro teaching (f:5). However, there were only a few suggestions on teaching skills in the class (f:7, 12.28\%) and planning skills (f:6, 10.53\%).

\section{Discussion and Conclusion}

In this metasynthesis research, important issues related to the contribution of school practicum to the teaching skills of pre-service teachers were identified. The most important contribution of this research was to reveal the general teaching skills regarded as important for the school practicum and identify gaps in acquiring these skills.

In the theoretical dimension of the examined studies, teaching competencies in faculty-school partnership models were mainly considered, with most focusing on the learning of teaching roles, and a few others focusing on social learning theory (observational learning), reflective thinking and the contribution of expert guidance. Many studies did not mention any specific theoretical model and only the benefits of the school practicum and the importance of practical experience were emphasised. Most studies, however, had a similar point of view. There was an absence of studies that examined specific teaching skills, learning to teach or the pedagogical content knowledge of pre-service teachers, which could be seen as an important gap in school practicum studies.

Most studies emphasized practicum problems, with positive attainments focused on far less. Based on these results, it could be said that school practicum experiences might not contribute effectively to the development of teaching skills in pre-service teachers. Similarly, Kasapoglu (2015) found that, in school practicum studies, more practicum problems were reported than benefits for pre-service teachers.

Pre-service teachers were generally found to have problems with teaching skills in the class, of which classroom management and teaching management were particularly mentioned. It appeared from these studies that pre-service teachers have problems in transferring their theoretical knowledge to the real classroom environment during the learning-teaching process. This result was consistent with Scheeler (2008). Another interesting finding was that there were very few studies that reported on the value of the pedagogical content knowledge in school practicum studies. In the examined studies, it was found that pre-service teachers tended to have problems articulating theoretical knowledge in practice and that their theoretical knowledge was missing or insufficient. Therefore, it could be concluded that the school practicum in Turkey does not appear to be effective in developing teaching skills or providing a unification of theory and practice. However, further research is needed to understand the bond between theory and practice 
(Korthagen \& Kessels 1999), so as to provide pre-service teachers with the ability to transfer their teaching skills to real classroom environments.

It was also found that pre-service teachers had difficulties organising and presenting content, which has been recognised as an important basic skill for effective teaching (Coskun 2013; InTASC 2011). However, it was highlighted that pre-service teachers needed more guidance on planning, materials selection, teaching strategies and assessment methods. The acquired teaching skills appeared to focus mainly on basic applications rather than on the more complex situations surrounding in-class teaching. To clarify these findings, the teaching skills and experiences of pre-service teachers regarding lesson organisation and presentation of content needs to be examined in greater detail.

When the benefits of the school practicum to pre-service teachers were examined, these tended to be reported negatively, in terms of the teaching skills missing and practicum limitations. It was generally agreed that the school practicum provided professional experience to pre-service teachers and developed their communication skills. However, the scope of professional experience is wide, so the teaching skills that need to be acquired and the quality of this experience need to be researched further. Moreover, it was apparent that the pedagogical content knowledge and the organisation and presentation of content needs to focus more on pre-service teachers to gain the supposed benefits.

As there were many problems raised regarding the teaching practicum, the studies also gave a range of suggestions to increase the efficacy of the practicum. One of the most frequently mentioned suggestions was that pedagogical content knowledge courses be delivered practically rather than theoretically. However, few practical suggestions regarding classroom management, teaching management, variety in teaching (Borich 2014) and use of material were given. The problems found in the teaching of concepts, principles or processes and solutions to these problems deserve further attention.

Education is an activity that is socio-culturally structured (Brown et al. 1989). Thus, pre-service teachers need to be prepared for different teaching conditions to ensure the learning and academic success of the students. However, as has been discussed, major deficiencies were found in the development of teaching skills through the school practicum; yet, teaching skills were not examined in detail and different theoretical approaches were not adequately discussed.

\section{Recommendations}

Based on the results of this research, studies based on different approaches and which examine the contribution of the school practicum in Turkey to the development of teaching skills are needed. For example, the role of mentorship, which is quite new in Turkey, planning skills, and the organisation and presentation of content should be examined. In the studies examined, there was a main focus on general teaching skills, but pre-service teachers are also expected to have specific teaching skills for the different teaching stages and class levels. Therefore, how the school practicum contributes to the development of these specific teaching skills needs to be more comprehensively examined in future studies. Lastly, this research was limited to studies in a Turkish context. To generalise these results, further metasynthesis studies are required at the international level.

\section{Acknowledgements}

An earlier version of this paper was presented at the 2015 II ${ }^{\text {nd }}$ International Eurasian Educational Research Congress in Ankara, Turkey.

\section{References}

Allen, J. M., \& Wright, S. E. (2014). Integrating theory and practice in the pre-service teacher education practicum. Teachers and Teaching: Theory and Practice, 20(2), 136-151. http://dx.doi.org/10.1080/13540602.2013.848568

Bakir, S. (2014). The effect of microteaching on the teaching skills of pre-service science teachers. Journal of Baltic Science Education, 13(6), 789-801.

Borich, G. D. (2014). Etkili ögretim yöntemleri [Effective teaching methods] (B. Acat, Trans. Ed.). Ankara: Nobel Yayincilik.

Brown, J. S., Collins, A., \& Duguid, P. (1989). Situated cognition and the culture of learning. Educational Researcher, 18(1), 32-42. http://dx.doi.org/10.3102/0013189X018001032

Choy, D., Wong, A., Lim, K., \& Chong, S. (2013). Beginning teachers' perceptions of their pedagogical knowledge and skills in teaching: A three year study. Australian Journal of Teacher Education, 38(5), 68-79. http://dx.doi.org/10.14221/ajte.2013v38n5.6

Coskun, M. (2013). Icerigin ogretim icin duzenlenmesi. In Doganay, A. (Ed.), Ogretim ilke ve yontemleri (pp.83-127). [In Principles and Methods in Education Organization content for teaching]. Ankara: PegemA Yayincilik. 
Graham, P. (2005). Classroom-based assessment: Changing knowledge and practice through pre-service teacher education. Teaching and Teacher Education, 21, 607-621. http://dx.doi.org/10.1016/j.tate.2005.05.001

InTASC (Interstate Teacher Assessment and Support Consortium) (2011). Model core teaching standards: A resource for state dialogue. Washington: Council of Chief State School Officers.

Kasapoglu, K. (2015). A review of studies on school experience and practice teaching in Turkey. Hacettepe University Journal of Education, 30(1), 147-162.

Kauffman, D. (1992). Supervision of student teachers. ERIC Clearinghouse on Teacher Education, ERIC Digest: Washington DC. ED 344873.

Koc, I. (2012). Pre-service science teachers reflect on their practicum experiences. Educational Studies, 38(1), 31-38. http://dx.doi.org/10.1080/03055698.2011.567030

Koc, S., Ergezen, S., Ayas, A., Baki, A., Cepni, S., \& Kincal, R. (1998). Faculty-school partnership. Ankara: CHE/The World Bank, National Education Development Project on Pre-Service Teacher Education.

Korthagen, F. A. J., \& Kessels, J. P. A. M. (1999). Linking theory and practice: changing the pedagogy of teacher education. Educational Researcher, 28(4), 4-17. http://dx.doi.org/10.3102/0013189X028004004

Kucukoglu, A., Kose, E., Tasgin, A., Yilmaz, B. Y., \& Karademir, S. (2012). The teacher candidates' opinions regarding the effect of micro teaching implementation on teaching skills [Mikro ogretim uygulamasinin ogretim becerilerine etkisine iliskin ogretmen adayi gorusleri]. Journal of Educational Science Research: International e-Journal, 2(2), 19-32.

Lawson,T., Cakmak, M., Gunduz, M., \& Busher, H. (2015). Research on teaching practicum-a systematic review. European Journal of Teacher Education. http://dx.doi.org/10.1080/02619768.2014.994060

Miles, M. B., \& Huberman, A. M. (1994). Qualitative data analysis (2nd ed.). Thousand Oaks, CA: Sage Publications.

Oonk, W. (2009). Theory-enriched practical knowledge in mathematics teacher education. Chap. 2: Theory and practice in teacher education. Unpublished doctoral dissertation, Leiden University. Retrieved from https://openaccess.leidenuniv.nl/.../02.pdf?

Ozder, H., Isiktas, S., Iskifoglu, G., \& Erdogan, F. (2014). An evaluation of the practicum course of pre-school teacher education program in North Cyprus. Mersin University Journal of the Faculty of Education, 10(2), 1-13.

Qazi, W., Rawat, K. J., \& Thomas, M. (2012). The role of practicum in enhancing student teachers' teaching skills. American Journal of Scientific Research, 44, 44-57. http://www.eurojournals.com/ajsr.htm.

Saban, A., \& Coklar, A. N. (2013). Pre-service teachers' opinions about the micro-teaching method in teaching practice classes. The Turkish Online Journal of Educational Technology (TOJET), 12(2), 234-240.

Savin-Baden, M., \& Major, C. H. (2010) (Eds.). Qualitative research synthesis the scholarship of integration in practice. In M. Savin-Baden, \& C. H. Major (Eds.), New approaches to qualitative research: Wisdom and uncertainty, (pp.108-118). London: Routledge.

Scheeler, M. C. (2008). Generalizing effective teaching skills: The missing link in teacher preparation. J. Behav. Educ., 17, 145-159. http://dx.doi.org/10.1007/s10864-007-9051-0

Sen, A. I. (2010). Effect of peer teaching and micro teaching on teaching skills of pre-service physics teachers. Education and Science, 35(155), 78-88.

Senemoglu, N. (1991). A Study of Initial Primary Teacher Training in England with Implications for the System in Turkey. (Unpublished Resarch Report), The University of Leicester.

Strauss, A., \& Corbin, J. (1990). Basics of qualitative research. Newbury Park, CA: Sage publications.

Tok, S. (2010). The problems of teacher candidate's about teaching skills during teaching practice. Procedia Social and Behavioral Sciences, 2, 4142-4146. http://dx.doi.org/10.1016/j.sbspro.2010.03.654

Van Velzen, C., Volman, M., Brekelmans, M., \& White, S. (2012). Guided work-based learning: Sharing practical teaching knowledge with student teachers. Teaching and Teacher Education, 28, 229-239. http://dx.doi.org/10.1016/j.tate.2011.09.011 


\section{Appendix}

The Studies Examined in This Research

1. Akgün, N., Yıldız, K., \& Canbulat, A. (2003). Aday öğretmenlerin kendilerini bir öğretmen olarak algılamaları. $A \dot{I} B \ddot{U}$ Eğitim Fakültesi Dergisi, 3(2), 1-17.

2. Alkan, V., Şimşek, S., \& Erdem, A.R. (2013). Uygulama okullarındaki yönetici ve eğitici personelin okul deneyimi dersine ilişkin önerileri [The directors' and teachers' suggestions for the 'teaching experience' lesson]. NWSA-Education Sciences, 8(2), 245-260.http://dx.doi.org/10.12739/NWSA.2013.8.2.1C0585

3. Altıntaş, S., \& Görgen, İ. (2014). Sinif öğretmeni adaylarinin öğretmenlik uygulamasi üzerine görüşleri (Muğla Sitkı Koçman Üniversitesi örneği) [The opinions of pre-service teachers about teaching practice]. Turkish Studies, 9(8), 197-208.

4. Becit, G., Kurt, A. A., \& Kabakçı, I. (2009). Bilgisayar öğretmen adaylarının okul uygulama derslerinin yararlarına ilişkin görüşleri [Viewpoints of pre-service computer teachers on the advantageous of school practicum courses]. Anadolu Universitesi Sosyal Bilimler Dergisi, 9(1), 169-184.

5. Çetintaş, B., \& Genç, A. (2005). Almanca öğretmen adaylarının öğretmenlik uygulaması derslerine ilişkin görüş ve deneyimleri [Views and experiences of prospective german language teachers on practicum courses]. Hacettepe Üniversitesi Ë̆itim Fakültesi Dergisi, 29, 75-84.

6. Çiçek, Ş., \& İnce, M. L. (2005). Öğretmen adaylarının öğretmenlikuygulaması sürecine ilişkin görüşleri [Prospective teachers' views related to the teaching practice process]. Hacettepe J. of Sport Sciences, 16 (3), 146-155.

7. Demir ,Ö., \& Çamlı, Ö. (2011). Öğretmenlik uygulaması dersinde uygulama okullarında karşılaşılan sorunların sınıf ve okul öncesi öğretmenliği öğrenci görüşleri çerçevesinde incelenmesi: Nitel bir çalışma [Schools teaching practice lesson practice problems encountered the investigation of class and opinions of pre-school students: A qualitative study]. Uludă̆ Üniversitesi Ĕgitim Fakültesi Dergisi,24(1), 117-139.

8. Dursun, Ö. Ö., \& Kuzu, A. (2008). Öğretmenlik uygulaması dersinde yaşanan sorunlara yönelik öğretmen adayı ve öğretim elemanı görüşleri [Opinions of teacher candidates and supervisors regarding problems experienced in teaching practice]. Selçuk Üniversitesi Ahmet Keleşoğlu Ĕ̆itim Fakültesi Dergisi, 25, 159 -178.

9. Ekiz, D. (2006). Kendini ve başkalarını izleme: Sınıf öğretmeni adaylarının yansıtıcı günlükleri [Self-observation and peer-observation: Reflective diaries of primary student-teachers]. Illköğretim Online, 5(1),45-57.

10. Eraslan, A. (2008). Fakülte-okul işbirliği programı: Matematik öğretmeni adaylarının okul uygulama dersi üzerine görüşleri [A faculty-school partnership programme: Prospective mathematics teachers' reflections on school practice course]. Hacettepe Üniversitesi Eğitim Fakültesi Dergisi (H. U. Journal of Education), 34, 95-105.

11.Eraslan, A. (2009). İlköğretim matematik öğretmen adaylarının 'öğretmenlik uygulaması' üzerine görüşleri [Prospective mathematics teachers' opinions on 'teaching practice']. Necatibey Eğitim Fakültesi Elektronik Fen ve Matematik Eğitimi Dergisi (EFMED), 3(1), 207-221.

12. Ergenekon, Y., Özen, A., \& Batu, E. S. (2008). Zihin engelliler öğretmenliği adaylarinin öğretmenlik uygulamasina ilişkin görüş ve önerilerinin değerlendirilmesi [An evaluation of the views of mental retardation practicum students on teaching practicum]. Kuram ve Uygulamada Eğitim Bilimleri Dergisi, 8(3), 857-891.

13. Güven, İ. (2004). Sosyal bilgiler alanı öğretmen adaylarının okul uygulamalarına yönelik görüşleri üzerine nitel bir araștirma [A Qualitative study of perceptions of prospective social studies teachers towards school practices]. Kuram ve Uygulamada Eğitim Bilimleri Dergisi, 4(2), 271-300.

14. Kab, İ., \& Yılmaz, K. (2013). Sosyal bilgiler öğretmen adaylarının 'okul deneyimi' ve 'öğretmenlik uygulaması' derslerine yönelik görüş ve değerlendirmeleri [Social studies teacher candidates' thoughts about and evaluations of 'school experience' and 'teaching practicum' courses]. Humanitas International Journal of Social Sciences, 1, 197215.

15. Kana, F. (2014). Türkçe eğitiminde öğretmenlik uygulaması dersi: Bir durum çalışması [Teaching practice course in Turkish language teaching: A case study]. Tarih Okulu Dergisi (TOD), 7(17), 745-764. doi: http://dx.doi.org/10.14225/Joh447.

16. Akpinar, M., Çolak, K., \& Yiğit, E. Ö. (2012). Öğretmenlik uygulamasi dersi kapsaminda sosyal bilgiler öğretmen adaylarinin yeterliklerine yönelik uygulama öğretmenlerinin görüşleri [Cooperating teachers' opinions about social studies pre-service teachers' competencies in teaching practice course]. M. ̈̈. Atatürk Ĕgitim Fakültesi Eğitim Bilimleri Dergisi, 36, 41-67.

17. Arkün Kocadere, S., \& Aşkar, P. (2013). Okul uygulamaları derslerine ilişkin görüşlerin incelenmesi ve bir uygulama modeli önerisi [A review of views about student teaching courses and an application model proposal] Hacettepe Üniversitesi Eğitim Fakültesi Dergisi, 28(2), 27- 43. 
18. Koç, C. \& Yıldız, H. (2012). Öğretmenlik uygulamasının yansıtıcıları: Günlükler [The reflectors of teaching experiences: Diaries]. Eğitim ve Bilim, 37(164), 223-236.

19. Özen, A., Ergenekon, Y. \& Batu, S. E. (2009). Zihin engelliler öğretmenliği adaylarının uygulama okulları ve uygulama sınıf öğretmenleri hakkındaki görüşleri [The opinions of student teachers of teacher training program in mental retardation about the practicum schools and practicum teachers]. Anadolu Üniversitesi Sosyal Bilimler Dergisi, 9(1), 185-200.

20. Saracaloğlu, S. A., Yılmaz, S., Çöğmen, S. \& Şahin, Ü. (2011). Sınıf öğretmeni adaylarının okul deneyimi dersine ilişkin görüşleri [Pre-service teachers' views about school experience]. Mehmet Akif Ersoy Üniversitesi Eğitim Fakültesi Dergisi, 11(22), 15-32.

21. Sarıtaş, M. (2007). Okul deneyimi I uygulamasının aday öğretmenlere sağladığı yararlar konusundaki görüşlerin değerlendirilmesi [Evaluation of the opinions about the benefits of the application of experience to the teacher candidates]. Eğitim Fakültesi Dergisi, 20(1), 121-143.

22. Seçer, Z., Çeliköz, N., \& Kayalı, G. (2010). Okul öncesi öğretmenliği okul uygulamalarında yaşanan sorunlar ve çözüm öneriler [Problems in school practices in department of pre-school teaching and solution offers]. Yüzüncü Yll Üniversitesi Ĕ̈itim Fakültesi Dergisi, 7(1), 128-152.

23. Şimşek, N. (2013). Öğretmen adaylarının okul deneyimi ve öğretmenlik uygulaması derslerinde karşılaştıkları güçlüklerle ilgili algılarının belirlenmesi. Siirt Üniversitesi Sosyal Bilimler Enstitüsü Dergisi, 1.mku.dergipark.gov.tr/susbid/issue/17335/181021

24. Şimşek, S., Alkan, V. \& Erdem, A. R. (2013). Öğretmenlik uygulamasına ilişkin nitel bir çalışma [A qualitative study about teaching practice]. Pamukkale Üniversitesi Eğitim Fakültesi Dergisi, 34(2), 63-73.

25. Taşdere, A. (2014). Sınıf öğretmen adaylarının öğretmenlik uygulaması dersine yönelik yaşadıkları sorunlar ve çözüm önerileri [Classroom teacher candidates' problems regarding teaching practicum class and proposed solutions]. Turkish Studies, 9(2), 1477-1497.

26. Topkaya, Y., \& Tokcan, H. (2012). Öğretmenlik uygulaması dersi hakkında sosyal bilgiler öğretmen adaylarının görüşleri [Opinions of prospective social studies teachers' views about teacher practice course]. The Journal of Academic Social Science Studies, 5(7), 663-678.

27. Ünver, G. (2003). Öğretmenlik uygulamasında işbirliği: Bir durum çalışması [Collaboration on teaching practice: A case study]. Gazi Ĕ̈itim Fakültesi Dergisi, 23(1), 87-100.

28. Yapıcı, Ş. \&Yapıcı, M. (2004). Öğretmen adaylarının okul deneyimi I dersine ilişkin görüşleri [Pre-service teachers' opinions about school experience I course]. Ilköğretim online, 3(2), 54-59.

29. Yeşilyurt, E., \& Semerci, Ç. (2011). Uygulama öğretmenlerinin öğretmenlik uygulaması sürecinde karşılaştıkları sorunlar ve çözüm önerileri [The problems and their solutions of practice teachers in teaching practice process]. Akademik Bakış Dergisi, 27, 1-23.

30. Yiğit, N., \& Alev, N. (2007). Okul deneyimi dersinde özel danışmanlık hizmetlerinin mesleki gelişime katkısının incelenmesi [An investigation on the contribution of one-on-one coaching to professional development in school experience course]. Necatibey Eğitim Fakültesi Elektronik Fen ve Matematik Eğitimi Dergisi (EFMED), 1(1), 85-101.

31. Yurdatapan, M. (2010). Fen ve teknoloji dersi öğretmen adaylarının öğretmenlik uygulaması dersi sirasındaki öğretmen rollerinin değerlendirilmesi [The assessment of teacher role of pre-service science teachers during the class of teaching practice]. M.Ü. Atatürk Ë̆itim Fakültesi Ĕ̈itim Bilimleri Dergisi, 31, 177 - 191.

32. Göktaş, Ö., \& Şad, S. N. (2014). Okul deneyimi ve öğretmenlik uygulaması dersi uygulama öğretmenlerinin seçim süreci: Ölçütler, sorunlar ve öneriler [Assigning the practice teachers for school experience and teaching practice courses: Criteria, challenges and suggestions]. Hacettepe Üniversitesi Eğitim Fakültesi Dergisi, 29(4), 115-128.

33. Baştürk, S. (2009). Öğretmenlikuygulamasıdersininöğretmenadaylarınıngörüşlerinegöreincelenmesi [Investigating teaching practice course according to student teachers' opinions]. Illköğretim online, 8(2), 439-456.

34. Özdemir, A. \& Çanakçı, O. (2005). Okul deneyimi I dersinin öğretmen adaylarının öğretim-öğrenme kavramlarına ve öğretmen-öğrenci rollerine bakış açıları üzerindeki etkileri [The effect of "school exprience I" course on Turkish pre-service elementary mathematics teachers' understandings about the concepts of teaching- learning and student and teacher roles]. Illkögretim online, 4(1), 73-80.

35. Paker, T. (2008). Öğretmenlik uygulamasinda öğretmen adaylarinin uygulama öğretmeni ve uygulama öğretim elemanının yönlendirmesiyle ilgili karşilaştiklari sorunlar [Problems of student teachers regarding the feedback of university supervisors and mentors during teaching practice]. Pamukkale Üniversitesi Eğitim Fakültesi Dergisi, 1(23), 132-139.

36. Ünver, G., \& Kurşunlu , E. (2014). Okul öncesi öğretmen eğitiminde kuram uygulama bağlantsısı [Connecting the 
theory and practice in preschool teacher education]. Uluslararası Eğitim Programları ve Öğretim Çalışmaları Dergisi, 4(7), 39-54.

37. Nayir, F., \& Çınkır, Ş. (2014). Uygulama öğretmenleri, yöneticileri ve pedagojik formasyon öğrencilerinin okullarda öğretmenlik uygulamasinda karşilaştiklari sorunlar ve çözüm önerileri [Mentor teachers, administrators and pedagogical formation students' problems associated with teaching practice and possible recommendations]. Uluslararası Ĕgitim Programları ve Öğretim Çalışmaları Dergisi, 4(7), 71-86

38. Sonmez, D., \& M. Hakverdi Can (2010). Preservice science teachers' ability to identify good teaching practices. Procedia Social and Behavioral Sciences, 2, 4120-4124.

39. Tok, S. (2010). The problems of teacher candidate's about teaching skills during teaching practice. Procedia Social and Behavioral Sciences, 2, 4142-4146.

40. Yiğit, N., \& Alev, N. (2005). Etkili öğretmen yetiştirme açısından okul deneyimi derslerinin değerlendirilmesi [Evaluation of school experience courses in respect to effective teacher training]. Gazi Eğitim Fakültesi Dergisi, 25(1), 91-103.

41. Büyükgöze Kavas, A., \& Bugay, A. (2009). Öğretmen adaylarının hizmet öncesi eğitimlerinde gördükleri eksiklikler ve çözüm önerileri [Perceptions of prospective teachers about deficiencies of pre-service teacher education and suggestions]. Pamukkale Üniversitesi Eğitim Fakültesi Dergisi, 25( 1), 13-21.

42. Bekiroğlu, O. F., Kahveci, A., İrez, S., Şeker, H., \& Çakır. M. (2010). Fakülte-okul işbirliği modelinin değerlendirilmesi: Ortaöğretim fen alanları öğretmen adaylarının görüşleri. Journal of Turkish Science Education, 7(4), 148-168.

43. Kılınç, Y. (2014). A study on the school experiences of geography student teachers: Theory and practice. SDU International Journal of Educational Studies, 1(2), 88-98.

44. Arıkan, Y. D. (2009). Bilişim teknolojileri öğretmen adayları ve öğretmenlik uygulamasi dersi. Ege Eğitim Dergisi, 10(1), 1-231.

45. Tepeli, Y., \& Caner, M. (2014). Pedagojik formasyon program öğrencilerinin öğretmenlik uygulamasi ile ilgili görüşleri. Eğitim Bilimleri Araştırmaları Dergisi, 4(2). doi: http://dx.doi.org/10.12973/jesr.2014.42.17

46. Duman, G. (2013). Okul öncesi öğretmenliği lisans program öğretmenlik uygulamasi derslerinin öğrenci boyutunda değerlendirilmesi [Evaluating practicum experiences of early childhood education program from students' perspective]. [Özel Sayl], Kastamonu Eğitim Dergisi, 21(4), 1661-1674.

47. Arslan, N. (2014).Türkçe öğretmenlerinin etkili öğretmen davranışlarını gerçekleştirme düzeyleri [The level of Turkish teachers related to achieving effective teacher behaviors]. Kastamonu Eğitim Dergisi, 22(1), 291-304.

48. Yılmaz, M. (2006). Resim-iş eğitimi öğretmen adaylarının okul deneyimi I uygulamalarında karşılaştıkları sorunlar [The problems encountered by painting pre-service teachers in school experience I applications]. Gazi Eğitim Fakültesi Dergisi, 26(1), 165-185.

49. Çakır, M., Bekiroğlu, F. O., İrez, S., Kahveci, A. \& Şeker, H. (2010). Fakülte-okul işbirliği modelinin değerlendirilmesi: Uygulama öğretmenlerinin görüssleri [Evaluation of faculty-school partnership model: mentor teachers' perspectives]. M.Ü. Atatürk Eğitim Fakültesi Eğitim Bilimleri, 31, $69-81$.

50. Karaca, N. H., \& Aral, N. (2011). Okul öncesi öğretmen adaylarının öğretmenlik uygulamalarında karşılaştıkları sorunlar. Journal of Educational and Instructional Studies in the World, 1(1), 140-147.

51. Baştürk, S. (2010). Matematik öğretmen adaylarının uygulama okullarında anlattıkları derslerin niteliği [Character of mathematics student teachers' lecturing in the schools]. M. Ü. Atatürk Eğitim Fakültesi Eğitim Bilimleri Dergisi, $31,57-68$.

52. Arslantaş, H. İ., \& Yıldız, M. A. (2013). Öğretmenlik uygulaması dersinin, uygulama öğretim elemanlari ve uygulama öğretmenlerinin görüşlerine gore değerlendirilmesi [Evaluation of "teaching practice" course according to the opinions of practitioner faculty members and teachers]. Celal Bayar Üniversitesi Sosyal Bilimler Dergisi, 11(1), 58-84.

53. Yeşilyurt, E, \& Semerci, Ç. (2012). Öğretmen adaylarının öğretmenlik uygulaması öğretim program bağlamında karşılaştıkları sorunlar ve çözüm önerileri [The problems that teacher candidates encounter during teaching practice curriculum and solutions offered]. International Journal of Human Sciences, 9(2), 475-499.

\section{$(\mathrm{cc}) \mathrm{BY}$}

This work is licensed under a Creative Commons Attribution 3.0 License. 